\title{
RISK IDENTIFICATION AND ANALYSIS IN A TRANSPORT COMPANY AS THE BASIS OF THE ORGANIZATION'S INSURANCE PROGRAM
}

\begin{abstract}
Business activity is exposed to market and individual threats of significant importance for its development. Responsible entrepreneurs should take actions focused on minimizing the impact of risk on the functioning of the organization and achieving market successes. Pilot studies confirmed the preferences of transport sector enterprises to limit potential risks at every stage of their operations. One of the solutions in risk management is its transfer to the insurer. The purpose of the presented article is to identify the most important problems related to risk in a selected transport company as a basis for preparing an insurance program ensuring optimal protection. For its implementation, an analysis of the business conditions of the audited entity was conducted, identification and analysis of possible risk was made, and scenarios of optimal protection were implemented through the application of a special risk management mechanism and its transfer to the insurer. The study is a contribution to selected issues and an attempt to present the results of the conducted research at the stage of creating a long-term offer of the insurance program as the protection of the enterprise against risk. The choice of the subject of research was intentional, as the entities providing TSL services are strongly threatened by the occurrence of risk in their operations.
\end{abstract}

Keywords: economic risk, transport company, insurance program

JEL: G22 


\section{Introduction}

Risk is an inherent element of economic activity in the market economy and the result of the impact of diverse and variable macroeconomic (inflation, interest rate, foreign exchange rates, international economic conditions) and microeconomic factors (including factors specific to the sector, industry, applied technologies, conditions and market relations, competitive and others).

Risk management is the key issue of functioning of modern enterprises. It should be perceived as an important element of the planning system, decision-making choices and managerial control. The main objective of process activities in this area is to identify potential areas, the scale of possible risk, its impact on the functioning of an organization and the selection of rational decisions determining its minimization. They should constitute the content of market strategies of enterprises, including the TSL sector, enabling shaping of the market position and achieving the advantage of enterprises in conditions of competitiveness.

\section{Theory (synthetic approach) and research methodology of the issues}

Risk is an interdisciplinary concept and quite difficult to clearly specify. Colloquially, it may be defined as managing the probability of events accompanying business operations. The literature on the subject presents many types of risks, including: external, internal, proper, subjective, objective, normal, acceptable, unacceptable, necessary, related to: effect, occurrence of alternatives, measurability of effects, range of occurrence.

The common nature of the phenomenon in the practice of management resulted in the fact that this issue is widely taken up in the literature on the subject and the scope of defining the concept depends on the context of the analyzes undertaken.

Z. Bodie and R.C. Merton (2003) described the risk as a significant uncertainty of impact on the prosperity of stakeholders. E. Vaughan and T. Vaughan (2007) defined the risk as conditions in which there is a probability of disturbing the expected result. D. Gołębiewski (2010) presented the risk as a probability of loss. Considerations regarding the interpretation of the concept and risk in Polish legislation were summarized by B. Kucharski (2013), giving various definitions in which the following were presented:

- possibility of loss,

- the probability of incurring a loss,

- the state in which there is a probability of incurring a loss,

- distribution of actual and expected results,

- deviation of the obtained result from the expected result,

- uncertainty,

- danger,

- subject of insurance. 
One of the possible actions to reduce the risk, in accordance with the standard announced by the European Association for Risk Management FERMA, is its financing, among others, through insurance. A properly prepared insurance program allows to reduce risk by transferring it to the insurer. According to Kucharski (2012), the preparation of such a program requires identification and analysis of the risk resulting from the activity and property owned. An important role in this process belongs to an insurance broker participating in the risk management process, including at its earliest stages. The insurance broker is a representative and proxy of the insurer, professionally involved in mediating in concluding the insurance contract (Kowalewski, 2012).

However, Malinowska (2013) pointed to the usefulness of reliably defined risk in the process of analytical proceedings and the choice of forms of its mitigation.

Risk management in enterprises should be an element of the managerial planning and control system, whereas a targeted audit may be performed by a representative of the enterprise or an external entity. In transport activity, the uncertainty and risk of production activity deserve attention, including scientific and technical progress as well as technical and technological progress generating the risk of economic aging of processes and services, innovative stress, environmental dangers and market risk (changes in demand and supply of services) as a result impact of external factors on enterprises and entrepreneurs in this industry. One should also remember about the risk of financial activity in cases of investing in securities (shares, bonds, etc.) which mainly concerns investors in transport infrastructure facilities.

Correct identification and analysis of business risk requires complexity and precision of performance, based on a very good knowledge of the analyzed enterpriseits objectives, conditions for their implementation and market assessment, taking into account the legal, social, cultural and political environment. Risk management in enterprises should be an element of the managerial planning and control system, whereas a targeted audit may be performed by a representative of the enterprise or an external entity.

A number of methods to classify the identification and measurement of risk that can be used depending on specific and specific economic situations have been developed. Risk identification consists in indicating potential factors (potential incidents) and determining their impact on the likelihood of risk occurring to achieve the organization's goals. It is a cognitive activity supporting the process of analysis, assessment and measurement of threats. The basis for risk measurement and assessment should be the result of identification of areas, factors and possible consequences of threats to the organization's activities. A risk metric in the form of a systematic review of typical risk factors and assigning appropriate measures to them may also be created.

Risk analysis, in accordance with the Risk Management Standard FERMA (2003), covers its identification, description and specific measurements. According to the ISO 31000: 2012 norm, this should be done in two separate, progressing stages. Mentel (2011) considered phased as a fundamental rule in the risk management process.

Own research was designed, aimed at risk identification and analysis in transport company $X$. The obtained results constituted the basis for negotiating 
a comprehensive offer of the risk management insurance program in the audited entity along with the transfer to the insurer. Risk identification and analysis was made using:

- case study of company X,

- causal analysis of accidents,

- an estimation method,

- deduction method.

The research process used data provided by the brokerage office, listed in the company's fixed assets register, omitting the total value of land, intangible assets and legal means. The information resulting from direct observations conducted by the transport company $\mathrm{X}$ was also taken into account. The results of the conducted research were presented in the further part of the study.

In the financial plans of enterprises, economic risk can or should be perceived as potential financial results, reduced by possible losses due to changes in the external environment. Possible losses can be seen as incurred costs or in the financial plans (projections) only take into account fully secured revenues. One of the possible actions to limit the risk, in accordance with the standard of the European Association for Risk Management FERMA, is its financing through e.g. insurance. A properly prepared insurance program allows to reduce risk by transferring it to the insurer.

According to B. Kucharski (2012), the preparation of such a program requires identification and analysis of the risk resulting from the activity and property owned. An important role in this process belongs to an insurance broker participating in the risk management process, possibly at its earliest stages. The insurance broker is a representative and proxy of the insurer, professionally involved in mediating the conclusion of the insurance contract (Kowalewski, 2012).

Transport companies are struggling with risks reinforced by the specificity of their activities. It usually takes place outside their headquarters, and the probability of an undesirable event is difficult to estimate. A special aspect is also: spatio-temporal spread of the transport service, the environment in which the transport takes place and the multitude of entities involved in the production process of services (drivers, passengers, freight forwarders, carriers, third parties) and items (means of transport, diversity of loads, etc.) (Cyganik, 2014). The scale of threats and risks in the process of providing transport services means that the risk and costs of potential damages and losses can significantly disrupt the financial liquidity of service providers. Hence, an important role is played by well and regularly performed risk identification, which is the basis for choosing a risk management instrument and optimal insurance protection.

\section{Characteristics of the subject of research}

The researched transport company $X$ is located near the western Polish border. It has the necessary licenses to practice the national and international road carrier. It offers complex transport, forwarding and logistics services (warehousing), tailored to the individualized preferences, expectations and needs of customers. It employs 40 employees including forwarders, drivers, warehousemen and office workers. 
Company $\mathrm{X}$ has a modern fleet of vehicles. It operates a fleet of 20 depots of MEGA trailer type equipped with movable curtains, most of them with a height of $3 \mathrm{~m}$ with raised ceilings. The loading space of vehicles (over $100 \mathrm{~m}^{3}$ ) enables the transport of oversized cargo, including large volumes. MEGA type semi-trailers are equipped with the necessary safeguards for the correct carriage of goods such as transport belts, non-slip mats, and barrier beams. Effective fleet management enables the GPS system to be equipped.

The territorial scope of the company's transport activity covers the whole of Europe excluding the Commonwealth of Independent States. It also carries out cabotage operations in European Union countries and in this part of the operating activity the company uses the services of subcontractors.

The assortment's structure is made up of packaging, food products, electronic equipment and home appliances, alcohol and tobacco products, perishable goods, dangerous goods, covered by ADR contracts (chemical articles and cosmetics in the solid state) and others in line with orders.

An important element of the fixed assets of enterprise $X$ is a modern warehouse and distribution center, in which the following services are provided:

- short-term and long-term storage of goods,

- reloading,

- cross-docking,

- marking,

- labeling,

- quality and quantity control of goods,

- customs service.

In the storage facility (steel hall) a social and office part was also separated. In addition, the company has valuable electronic equipment, estimated at about 5\% of the total value of fixed assets.

The elements exposed at risk indicated by the enterprise $X$ are:

- building and company property (property excluding vehicles and electronics), which constitutes approximately $59 \%$ of the total value of fixed assets,

- employees,

- vehicle fleet,

- company's activity:

- storage,

- transport on the domestic market,

- transport on the international market

- cooperation with subcontractors,

- forwarding with the trade in goods owned by customers.

\section{Risk in a transport company $X$ - explication of research results and discussion}

In the financial plans of enterprises, economic risk can or should be perceived as potential financial results, reduced by possible losses due to changes 
in the external and internal environment. Possible losses can be treated as incurred costs or in the financial plans (projections) only take into account fully secured revenues.

The designed research consisted of risk identification in the transport company $X$. It was carried out using the following research methods:

- case study of enterprise X,

- causal analysis of damage accidents,

- estimation method,

- deduction method.

The research process used data made available by the brokerage office, shown in the company's fixed assets register excluding the total value of land, intangible assets. The information resulting from direct observations carried out by the transport company $X$ was also taken into account. The results of the conducted research are presented in the further part of the study.

Transport companies struggle with the risk reinforced by the specificity of their operations. It usually occurs outside of their premises, often in remote markets, and the probability of an undesirable incident is difficult to estimate. A special aspect is also the so-called spatiality of the transport service, environment in which transport takes place and the number of entities involved in the service production process (drivers, passengers, freight forwarders, carriers, third parties) and objects (means of transport, variety of loads, etc.). The scale of threats and risks in the process of providing transport, forwarding and logistics services means that the risk and costs of potential damages and losses can significantly deform the financial liquidity of service providers. Hence, an important role is played by good and regular risk identification, which is the basis for selecting risk management instruments and optimal insurance protection.

Due to the fact that the source of potential economic risk and threats of the transport company $X$ are internal and external factors, the functionally different components of the company were considered separately.

A modern fleet of vehicles is a high value of the assets of the transport company $X$ (about $36 \%$ of the value of fixed assets). Means of transport are also used outside the country, which causes the risk of theft and loss of vehicles also with cargo. Although company $X$ does not provide services in, for example, the Commonwealth of Independent States (CIS), Ukraine or Belarus, where uncertainty is higher than in the rest of Europe, the problem should not be underestimated in the context of, for example, possible terrorist acts, brash acts or other unworthy behavior. During the operation of vehicles there is also a risk of damaging them in road accidents, other undesirable incidents and damages in parking places. The drivers or other road users, parking lots, dedicated cargo handling areas etc. may be responsible for the occurring incidents. Apart from damage to own vehicles, there is also the risk of damage, destruction, partial or total loss of third party property. In addition, there may be damage to windows, car bodies and tires when driving due to other events such as stones falling from under the wheels or falling objects from other vehicles in motion, lawnmowers ordering roadside belts, etc. Also the risk of random damage to vehicles is not without significance that result in their immobilization due to technical and random failures, e.g. unforeseen failures, fall of trees (branches) 
on the vehicle in strong wind, destruction of wires by animals, as well as failure to deliver "just in time" - for the time specified in the contract with the client about the date of service.

In the context of road accidents, apart from property damage, personal injuries may occur, including drivers, passengers and third parties. These include hitting a pedestrian, resulting in damage to health, internal and external damage, the necessity of medical procedures, long-term rehabilitation or death.

Storage services provided by enterprise $\mathrm{X}$ include storing and securing customers' property for a fixed period of time in individual contracts. Their conclusion is synonymous with the acceptance of obligations with full responsibility for damage caused to the entrusted property, and in the event of failure to do so, to compensate them for the benefit of the creditor.

Based on the identification and risk analysis, it can be concluded that transport activity of transport company $\mathrm{X}$ in most cases generates a risk of damage to the transported goods, for which, in accordance with the contract concluded with the customer, the carrier bears full responsibility. For example, a violent driver maneuver may result in the loss of the load or its usefulness, which is for the customer an attitude of compensation claims corresponding to the damage value.

Another example of damage suffered by the researched carrier on the international transport market entitling the customer to obtain compensation was breaking into a third party vehicle and damage, destruction or theft entrusted to the carriage of cargo (e.g. in Calais / France - the end of 2017, Asian and African aggression refugees waiting for the possibility of transfer to Great Britain).

Additionally, by commissioning the contract, transport company $\mathrm{X}$ bears the risk of improper activities of subcontractors, including the lack of due diligence in the implementation of the services ordered. An example of such damage was the transport of exotic fruit (mandarins) from Greece to Poland at the wrong temperature. Company $X$ was obliged to refund the monetary equivalent of the damaged product.

Another real risk for the company may be the loss of professional competence, including the license permit (certificate) as a result of non-compliance with the KREPTD (National Electronic Register of Road Transport Entrepreneurs) rules. In Poland, it has been in force since November 2017 as a database of the Main Road Transport Inspector fulfilling the function of a platform for exchanging information on companies, managers, vehicles and domestic and foreign violations (www.biznesistyl.pl).

The forwarding activity of the studied transport company $\mathrm{X}$ in the aspect of responsibility for the selection of a trusted carrier and the proper execution of the order is also burdened with risk. The result of the wrong choice may be, for example, the loss of the object of carriage or its assets, which entitles the customer to claim and obtain appropriate compensation. Another example of damage due to the forwarder's liability is failure to comply with the assumptions described in the contract / order. For example, the forwarder may choose a warehouse that does not meet the desired requirement of a limited level of storage humidity etc., which entitles the customer to claim compensation for loss of value, lost value and disposal costs. 
The storage facility of the transport company $\mathrm{X}$ with an office part was located in a fenced and guarded area. In addition, an alarm system was installed in it with the function of notifying property protection agencies. In the process of identification and analysis of threats, which originated from the external surroundings of the facility, the risk of theft with burglary, devastation and fire hazard resulting from the construction of the building was indicated (steel hall with roofing and wall cladding from the sandwich panel).

The social and office part of the warehouse is separated by a fire wall, consistent with the regulations and fire protection. However, it is not possible to fully exclude the risk of fire as a result of, for example, electrical system malfunction. Therefore, the real risk of total destruction of the hall under the influence of fire and plastic properties of steel at high temperatures was indicated. An additional fire threat is people employed in the facility, e.g. smoking workers. The risks also include sickness absence of the staff, which limits current production efficiency and generates losses for the company.

Summing up the presented content and facts, it should be stated that the $X$ transport company is predestined for multi-faceted threats and risks. Potential threat is internal and external factors, which can significantly affect the stability of operations and financial liquidity of the company. Complex identification and analysis of potential sources of risk is therefore an indispensable basis for preparing and negotiating a favorable insurance program, ensuring protection through risk transfer to the insurer.

To sum up the presented content and facts, the transport company $\mathrm{X}$ is exposed to various types of threat and risk, which were identified in the conducted research and whose source are presented internal and external factors. Potential damages, examples of which are cited above, can significantly undermine the company's financial liquidity. Comprehensive risk identification is an unquestionable basis for preparing an insurance program that will provide optimal protection against the financial effects of risk implementation by transferring risk to the insurer.

\section{Conclusions}

Transport activities are exposed to potential and unforeseen risks resulting from the simultaneous production and consumption of services generally provided outside the enterprise. They are favored by numerous macroeconomic, legislative, geographical, economic and microeconomic determinants, including market and random ones. The risk management process requires systematic research of the components of the conducted activity as well as professional analyzes of possible threats. Detailed risk identification and in-depth analyzes of the areas of the company's operation are the undisputed basis for developing useful and, above all, beneficial solutions. At this stage of diagnoses and decisions, professional expert support is often important.

The implementation of risk in the operations of a transport company involves with measurable costs-in the event of large damage, it may undermine the company's financial liquidity. Therefore, it is important to adopt appropriate risk 
management methods. Research conducted for the purposes of the article provides the basis for using risk financing by the insurer.

In conclusion, it should be emphasized that the article attempts to identify and assess the risk of the selected organization managing TSL market. For the correctness of the research process, the definition of the probability of risk occurrence as a sudden, unforeseen, undesirable event and generating measurable market, economic and financial losses to the enterprise X. Together with the identification, assessment and risk analysis it was a desirable component of the process of correct preparation of a comprehensive insurance program for enterprise $X$, providing transport, forwarding and logistics services on a national and international scale. The content presented in the article is the result of the conducted research, and their results will be published in subsequent publishing editions. The preparation of such an insurance program with an indication of the appropriate types of business insurance, clauses extending the basic scope of insurance and the appropriate selection of insurance sums together with an explanation will constitute further research.

\section{References}

Bodie, Z., Merton, R.C. (2003), Finanse, Polskie Wydawnictwo Ekonomiczne, Warszawa, p. 364.

Cyganik, J. (2014), Ryzyko w transporcie drogowym - źródła i wielkość szkód, Logistyka, 3, pp. 31-36.

Federation of European Risk Management Associations (FERMA) (2003), Standard zarządzania ryzykiem, Warszawa.

Gołębiewski, D. (2010), Audyt ubezpieczeniowy. Praktyczne metody analizy ryzyka, Poltext Sp. z o.o., Warszawa, p. 37.

Kowalewski, E. (2012), Kim jest broker na rynku ubezpieczeniowym-kilka refleksji na tle wielofunkcyjności i aleatoryjności profesji brokera ubezpieczeniowego. In: Serwach, M. (Ed.), Broker w świetle prawa i praktyki ubezpieczeniowej, Wydawnictwo Uniwersytetu Łódzkiego, Łódź, p. 29.

Kucharski, B. (2012), Broker jako pośrednik handlowy. In: Serwach, M. (Ed.), Broker w świetle prawa i praktyki ubezpieczeniowej, Wydawnictwo Uniwersytetu Łódzkiego, Łódź, p. 68.

Kucharski, B. (2013), Umowa o zarządzanie ryzykiem. In: Serwach M. (Ed.), Ryzyko ubezpieczeniowe. Wybrane zagadnienia teorii i praktyki, Wydawnictwo Uniwersytetu Łódzkiego, Łódź, p. 199.

Malinowska, K. (2013), Zarządzanie ryzykiem w ubezpieczeniach mienia. In: Serwach, M. (Ed.), Ryzyko ubezpieczeniowe. Wybrane zagadnienia teorii i praktyki, Wydawnictwo Uniwersytetu Łódzkiego, Łódź, pp. 130-131.

Mentel, G. (2011), Value at risk w warunkach polskiego rynku kapitałowego, CeDeWu, Warszawa, p. 20.

Vaughan, E.J., Vaughan, T.M. (2007), Fundamentals of risk and insurance, John Wiley\&Sons, Inc., New York.

Wróblewski, D. (Ed.) (2015), Zarządzanie ryzykiem - przegląd wybranych metodyk, Wydawnictwo CNBOP-PIB, Józefów, p. 30.

www.biznesistyl.pl [Accessed 3 March 2019].

\section{Contacting author}

Danuta Rucińska can be contacted at: danuta.rucinska@ug.edu.pl 